\title{
Detection of toxic chromium species in water using cell- based sensor systems
}

\author{
Ulrich Bohrn ${ }^{1,2,3}$, Andreas Mucha ${ }^{1}$, Carl F. Werner ${ }^{2}$, Evamaria Stütz ${ }^{1}$, Matthias Bäcker ${ }^{2}$, \\ Christoph Krumbe ${ }^{2}$, Meinrad Schienle ${ }^{1}$, Maximilian Fleischer ${ }^{1}$, Patrick Wagner ${ }^{3}$, Michael J. Schöning ${ }^{2}$ \\ ${ }^{1}$ Siemens AG, Corporate Research \& Technologies, Otto-Hahn-Ring 6, Munich, Germany \\ ulrichbohrn@hotmail.com \\ ${ }^{2}$ Aachen University of Applied Sciences, Institute of Nano- and Biotechnologies (INB), Heinrich- \\ Mussmann-Straße 1, Jülich, Germany \\ ${ }^{3}$ Hasselt University, Institute for Materials Research (IMO/IMOMEC), Wetenschapspark 1 , \\ Diepenbeek, Belgium
}

\begin{abstract}
:
In this study, several cell-based sensor systems have been evaluated and compared for their usability as environmental sensors in aquatic systems. Toxic chromium( $(\mathrm{VI})$ ions as well as non-toxic chromium(III) ions have been used as model substances, since chromium pollutions are of major concern. The investigated systems perform impedance, acidification and oxygen consumption measurements as well as combinations of these parameters. With multi-parametric sensor systems, the detection of $\mathrm{Cr}(\mathrm{VI})$ contamination is possible even at the limit of drinking water regulations $(0.5 \mu \mathrm{M}$ $\mathrm{Cr}(\mathrm{VI})$ ). Oxygen consumption seems to be the most sensitive parameter as it increases at lowest concentrations within 3 hours. The continuous recording of physiologically relevant data even shows the early beginning of a toxic reaction. Tested V79 hamster lung fibroblast cells react only towards the presence of toxic $\mathrm{Cr}(\mathrm{VI})$, while non toxic $\mathrm{Cr}(\mathrm{III})$ is not impairing the cellular physiology or morphology. The use of living cells in combination with sensor technology is promising to have a major impact in the field of broad-band environmental sensors.
\end{abstract}

Key words: Chromium(VI), cell-based sensor, LAPS, impedance, oxygen consumption, acidification

\section{Introduction}

Cell-based sensors are supposed to be valuable tools for the detection of unexpected toxic substances in aquatic environments [1]. Several cell-based sensor tools are currently on the market but most of them are originally developed for life science and medical purposes [2-4]. Some commercially available systems were tested and compared with novel sensor setups [5] to investigate the usability as environmental sensors. Chromium ions were used as model substances for the evaluation. $\mathrm{Cr}$ is present in the environment in two main oxidation states: $\mathrm{Cr}(\mathrm{VI})$ and $\mathrm{Cr}(\mathrm{III})$. While $\mathrm{Cr}(\mathrm{III})$ is an essential nutrient which is present in nonpolluted environments, $\mathrm{Cr}(\mathrm{VI})$ is a highly toxic metal that readily crosses the cell membrane. In contrast to traditional detection methods, like ion chromatography [6] and atomic-absorption spectrometry [7], living cells are supposed to react only towards the cytotoxic $\mathrm{Cr}(\mathrm{VI})$ species.

\begin{abstract}
Material and methods
V79 Chinese hamster lung fibroblasts were applied as sensitive eukaryotic cell line as it is known that $\mathrm{Cr}(\mathrm{VI})$ induces damages in the respiratory tract of mammalians. Cells were cultured in Dulbecco's Modified Eagle Medium (DMEM) and grown on the surface of the sensor chips prior to the substance exposure (see Fig. 1). The investigated sensor systems are listed in Table 1. In contrast to the other three sensor systems, the cells in the lightaddressable potentiometric sensor system (LAPS) are grown on a membrane, which is placed over the silicon chip. Further information regarding the detailed measurement protocols of the individual devices can be found in references [2-5]. The cells formed a confluent monolayer within 16-20 hours. During the measurement, the cells are constantly covered with Hepes-buffered running medium (RM). Chromium solutions are diluted in running medium to set up the different concentrations.
\end{abstract}


Tab. 1: Cell-based sensor systems

\begin{tabular}{|c|c|c|}
\hline Sensor System & $\begin{array}{l}\text { Detection } \\
\text { method }\end{array}$ & $\begin{array}{c}\text { Limit of } \\
\text { Cr(VI) } \\
\text { detection }\end{array}$ \\
\hline $\begin{array}{c}\text { Bionas } 2500 \\
\text { Analyzing } \\
\text { system [2] }\end{array}$ & $\begin{array}{c}\text { oxygen } \\
\text { consumption, } \\
\text { acidification, } \\
\text { impedance }\end{array}$ & $0.5 \mu \mathrm{M}$ \\
\hline $\begin{array}{c}\text { LAPS } \\
\text { Cytosensor }^{\circledR} \text { [3] }\end{array}$ & acidification & $50 \mu \mathrm{M}$ \\
\hline $\begin{array}{c}\text { xCELLigence }{ }^{\circledR} \\
{[4]}\end{array}$ & impedance & $5 \mu \mathrm{M}$ \\
\hline $\begin{array}{c}\text { CMOS sensor } \\
{[5]}\end{array}$ & impedance & $10 \mu \mathrm{M}$ \\
\hline
\end{tabular}

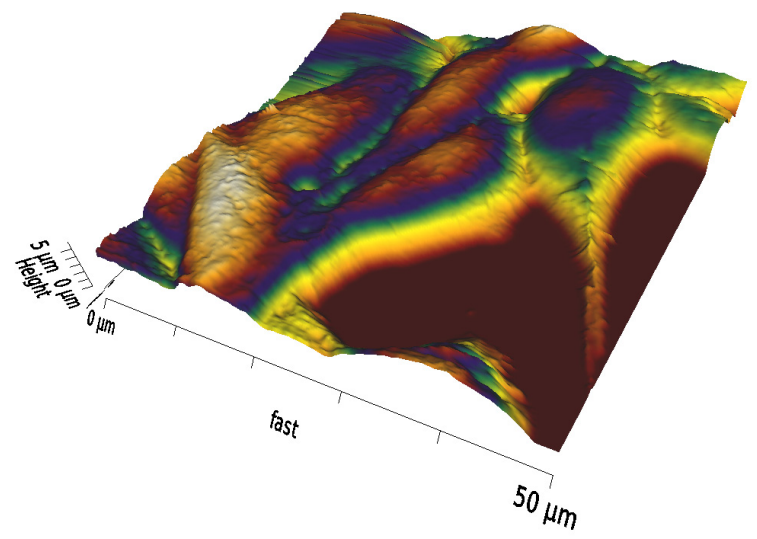

Fig. 1. Atomic force microscopy image of V79 Chinese hamster lung fibroblast cells grown on an untreated silicon surface. Untreated cells form a cell monolayer on the surface.

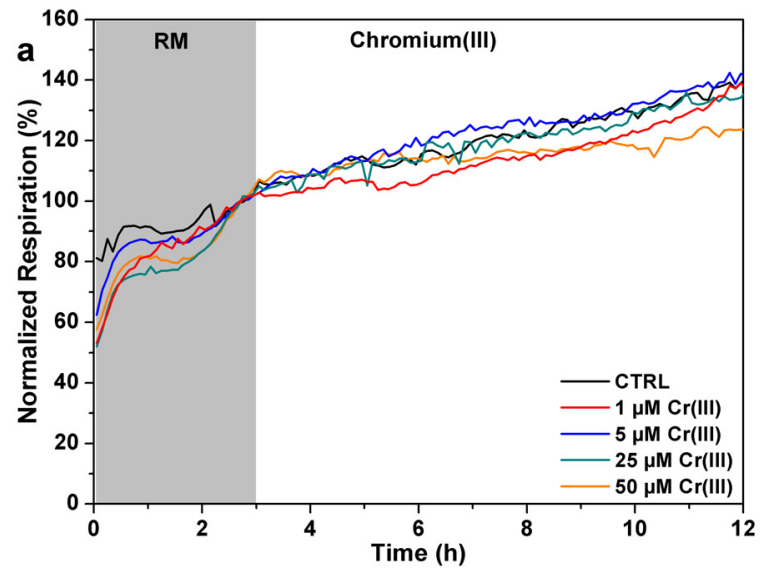

\section{Results}

One general advantage of cell-based sensors is the fact, that only the bioavailable fraction of the metal is part of the signal generation process. Non-toxic $\mathrm{Cr}$ (III) ions did not result in a signal of the cell-based sensors (see Fig. $2 a$ and $3 a$ ). In contrast, $\mathrm{Cr}(\mathrm{VI})$ could be detected at concentrations down to $0.5 \mu \mathrm{M}$, which is the limit of the European drinking water directive [8]. Significant changes in the oxygen consumption due to chromium occurred within 3 hours (see Fig. 2b). The best results regarding cell-impedance based measurements were achieved with the xCELLigence system. $\mathrm{Cr}(\mathrm{VI})$ concentrations of $5 \mu \mathrm{M}$ could be distinguished from the control measurements (see Fig. 3b). The 2500 Analyzing system and the CMOS sensor showed significant change in the impedance values for $10 \mu \mathrm{M}$ and $50 \mu \mathrm{M}$, respectively. Additional immunofluorescence staining confirmed the long-time effects of $\mathrm{Cr}(\mathrm{VI})$ on changes of the membrane as well as the induced oxidative stress leading to changes in the mitochondria pattern. The decrease in the acidification rates which were detected with the LAPS-based Cytosensor and the 2500 Analyzing system revealed also promising results (data not shown) but the detection time and the signal intensity were lower compared to the oxygen consumption results.

Standard cell cytotoxicity assays such as the MTT assay display a toxic reaction of the V79 cells at concentrations of $5 \mu \mathrm{M} \mathrm{Cr}(\mathrm{VI})$ and higher (see Fig. 4). The 2500 Analyzing system and xCELLigence system exceed these detection limits as they are able to detect $\mathrm{Cr}(\mathrm{VI})$ concentrations of $5 \mu \mathrm{M}$ and lower within 3-12 hours.

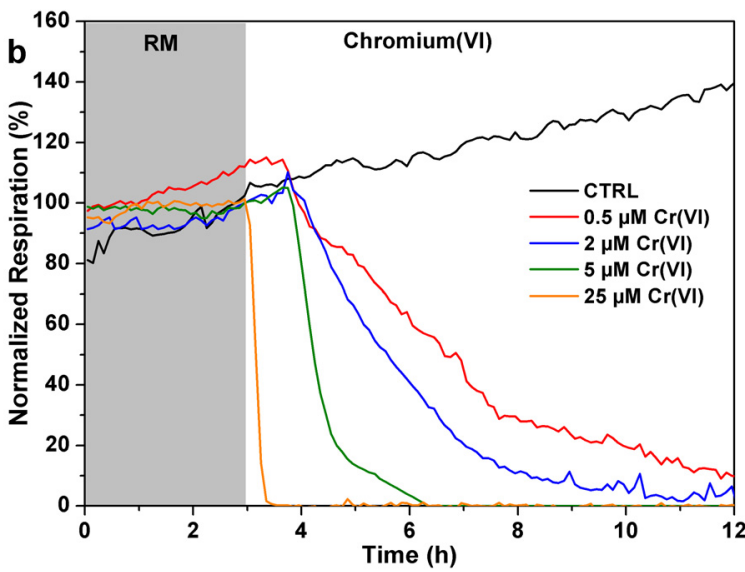

Fig. 2. Time transient of oxygen consumption measurements with the 2500 Analyzing system of V79 Chinese hamster lung cells after $3 \mathrm{~h}$ of adaption phase with untreated culture medium (RM) incubated with (a) non-toxic $\mathrm{Cr}$ (III) solution and (b) toxic Cr(VI) solution for 9 hours. Running medium and chromium solutions were pumped in a stop-go modus (3 $\mathrm{min} / 3 \mathrm{~min}$ ) over the cell monolayer. 

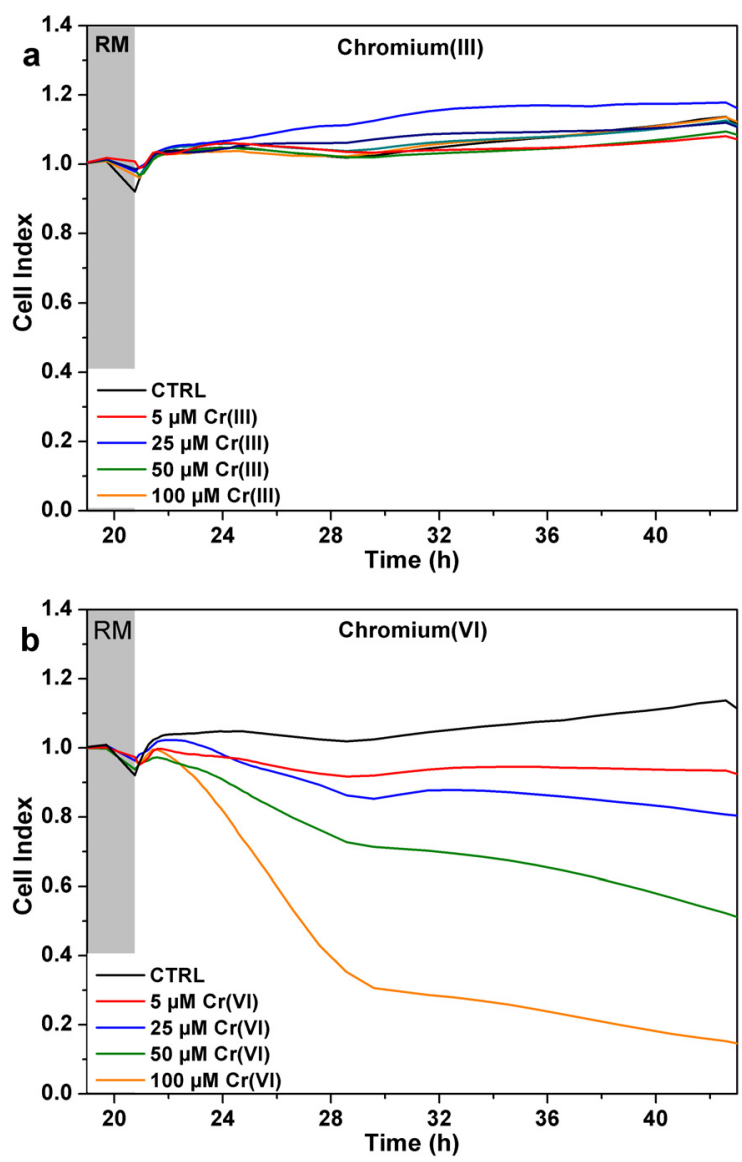

Fig. 3. Time transient of impedance measurements (xCELLigence system) of V79 Chinese hamster lung fibroblast cells incubated with (a) non-toxic $\mathrm{Cr}$ (III) solution and (b) toxic $\mathrm{Cr}(\mathrm{VI})$ solution for 24 hours. Cells are covered with liquid medium without a flow. Medium change from running medium to chromium solutions was done manually.

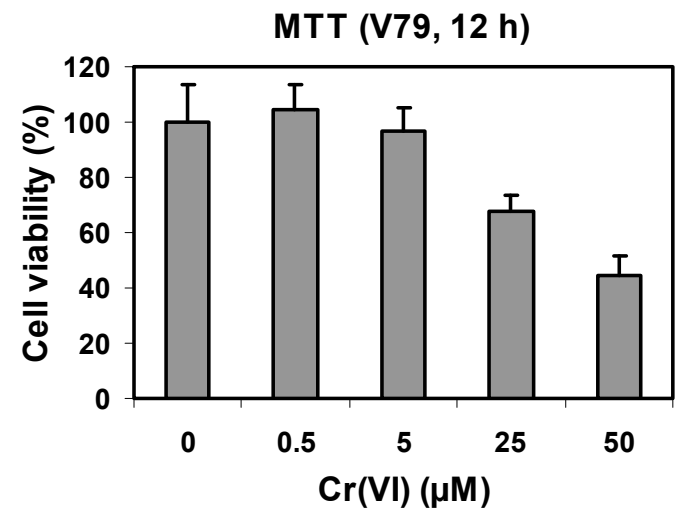

Fig. 4. Results of MTT cytotoxicity assay of V79 cells exposed to various concentrations of $\mathrm{Cr}(\mathrm{VI})$ for 12 hours. Measurements were done in triplicate. Error bars indicate standard deviation.

\section{Conclusion}

The results demonstrated the feasibility of cellbased sensor systems for the use as monitoring devices for metal pollutants in aquatic environments. Multi-parametric systems are favored as they can signalize the presence of a pollutant with different detection systems. The decrease in impedance, acidification and respiration takes place in a concentrationdependent way. The oxygen consumption is the most sensitive parameter for the detection of toxic $\mathrm{Cr}(\mathrm{VI})$ as it reacts towards the lowest concentrations $(0.5 \mu \mathrm{M})$ in short times (<3 hours). Non-toxic $\mathrm{Cr}(\mathrm{III})$ can be distinguished from $\mathrm{Cr}(\mathrm{VI})$ as no significant inhibition of the cellular parameters are observed, even at high concentration $(100 \mu \mathrm{M})$. Another advantage of the cell-based sensor systems in general is the higher time resolution, compared to those of standard cell culture assays. This opens the possibility to employ these sensors in early warning systems. The use of cell-based sensors as environmental sensors for the monitoring of aquatic systems, not only for chromium detection but also for other heavy metals or organic pollutants, seems to be within the realm of possibility.

\section{Acknowledgements}

The authors would like to thank Christian Guijarro and Thomas Schnitzler for their help with cell culture equipment.

\section{References}

[1] R. Kubisch, U. Bohrn, M. Fleischer, E. Stütz, Cellbased sensor system using L6 cells for broad band continuous pollutant monitoring in aquatic environments, Sensors 12, 3370-3393 (2012); doi: $10.3390 / \mathrm{s} 120303370$

[2] R. Ehret, W. Baumann, M. Brischwein, A, Schwinde, B. Wolf, On-line control of cellular adhesion with impedance measurements using interdigitated electrode structures, Med. Biol. Eng. Comput., 36:365-370. (1998); doi: 10.1007/BF02522485

[3] F. Hafner, Cytosensor ${ }^{\circledR}$ Microphysiometer: technology and recent applications, Biosensors \& Bioelectronics 15, 149-158 (2000); doi: 10.1016/S0956-5663(00)00069-5

[4] N. Yu, J.M. Atienza, J. Bernard, S. Blanc, J. Zhu, X. Wang, $X$. Xu, Y.A. Abassi, Real-time monitoring of morphological changes in living cells by electronic cell sensor arrays: an approach to study $\mathrm{G}$ protein-coupled receptors, Anal. Chem. 78:35-43 (2006); doi: 10.1021/ac051695v

[5] A. Mucha, U. Bohrn, M. Schienle, D. SchmittLandsiedel, CMOS integrated cell adhesion sensor for lab-on-a-chip applications, Proceedings of SPIE 8068, $80680 \mathrm{U}$ (2011); doi: 10.1117/12.886409

[6] M.J. Shaw, P.R. Haddard, The determination of trace metal pollutants in environmental matrices using ion chromatography, Environment 
International 30, 403-431 (2004); doi: 10.1016/j.envint.2003.09.009

[7] M.J. Marques, A. Salvador, A. Morales Rubio, M. de la Guardia, Chromium speciation in liquid matrices: a survey of the literature, Fresenius Journal of Analytical Chemistry 367, 601-613 (2000); doi: 10.1007/s002160000422

[8] Council Directive 98/83/EC of 3 November 1998 on the quality of water intended for human consumption. Official Journal of the European Communities 5.12.98, L330/32-L330/53. Available online: http://eurlex.europa.eu/LexUriServ/LexUriServ.do?uri=CO NSLEG:1998L0083:20031120:EN:PDF (accessed on 20th March 2012) 